\title{
KOMMUNIKATIIVSE SITUATSIOONI DÜNAAMILINE DIMENSIOON
}

Silvi Tenjes, Ingrid Rummo,

Kristiina Praakli

Ülevaade. Artiklis käsitletakse inimese suhtluse uurimist reaalses situatsioonis ning esitatakse multimodaalse suhtluse analüüs, milles näidatakse, kuidas suuline keel ehk kõnekeel üksi ei suuda kommunikatiivset tähendust esitada. Kommunikatiivsesse situatsiooni kui sotsiaalsesse tegevusse kuuluvad peale suhtlejate kõnekeele ka pilk, käeliigutus ning situatsioon tervikuna. Analüüs toob esile olulised inimese suhtlusmodaalsused.

Artiklis võrreldakse peamiselt sotsioloogide poolt läbiviidud uuringuid, mida nimetatakse konversatsioonianalüüsiks ehk vestlusanalüüsiks, ning lingvistide käsitletud diskursusuuringuid. Kui vestlusanalüüs on uurimismeetod, mis lubab suhtlus- ja käitumissituatsioone analüüsida, siis diskursusanalüüsi võib käsitleda uurimisvaldkonnana.

Suhtlussituatsioonis me kasutame oma erinevaid suhtlusvõimeid. Käežestid on oluliseks faktoriks tähenduste ja kavatsuste edasiandmisel, nendel peatutakse artiklis suhtlussituatsiooni tähenduse loomise temaatika juures. Defineeritakse multimodaalne suhtlemine, esitatakse videoainestike eelised materjalide kogumisel ja analüüsimisel. Analüüsitakse Patau sündroomiga tütarlapse erinevate modaalsustega suhtlust, seejuures tõdevad autorid, et suhtluse osapoolte koostööga ja multimodaalsete komponentide arvessevõtmisega kujuneb parem mõistmine suhtlussituatsioonis.*

Võtmesõnad: vestlusanalüüs, diskursusanalüüs, suhtlus, mittesõnaline keel, kognitsioon, kõnekahjustused, Patau sündroom

* Artikkel on valminud Eesti Teadusfondi grandi nr 8008 osalisel toel. Täname prof Helle Metslangi väärtuslike 


\section{Sissejuhatus}

Artiklis antakse ülevaade valdkonnast, mis on sotsiaal- ja humanitaarteaduste toimiva ühisosana saanud 21. sajandil oluliseks uurimisalaks: inimese suhtluse uurimisest reaalses situatsioonis, kirjeldades sealhulgas tema keelekasutust multimodaalses võtmes koos ümbritsevate ja käsitsetavate vahenditega.

Keeleteaduses käsitletakse inimese keelekasutust rõhuasetusega keelesisestel faktoritel: analüüsitakse suhtlejate kõnekeelt keeletasandite raamistuses semantika ja/või pragmaatika aspekte kaasates või ka sotsiolingvistilisi meetodeid rakendades. Keeleteaduse kui teadusdistsipliini sünnist alates 19. sajandil on suurim rõhuasetus olnud tekstide uurimisel ja analüüsil. Keele uurimine tema kasutuses on olnud küllaltki lühiajaline, jäädes peaasjalikult 20. sajandi teise poolde. Erinevate teoreetiliste aluste (Saussure, Peirce jt) ja sotsiaalmajanduslike põhjuste (II maailmasõda ja kodeeritud sõnumite dekodeerimine formaallingvistiliste meetoditega) tôttu oli 20. sajandi keeleteadus läbivalt ideaalkeele kategooriatega (Chomsky) ning strukturaal- ja formaallingvistiliste eelistustega valdkond. Peavoolust kõrvaletõrjutud muude keeleteaduse alldistsipliinide kõrval (morfoloogia, semantika, funktsionaalne keeleteadus) polnud ruumi ka inimesel - keele kasutajal reaalses sotsiaalses kontekstis.

Kommunikatiivsesse situatsiooni kui sotsiaalsesse tegevusse (Heath, Hindmarsh 2002) kuuluvad peale suhtlejate kõnekeele ka nende kehaliigutused - pilk ja käeliigutus (vt nt Kendon 1986, 1995, 2004, McNeill 1992, Streeck 1988, Streeck, Knapp 1992). Kommunikatiivse tähenduse seisukohalt on oluline situatsioon tervikuna (Schegloff 1984, Goodwin 1986, 2003, 2007). Keele mõiste pole siin enam kõnekeele ja tekstides leiduva kirjakeele tähenduses. Meie töödefinitsioon keele ja keeleuuringute jaoks on järgmine: keel on inimese kõne, käeliigutus, näoilme ja kehaliigutus üheskoos, ning ka kirjakeel. Keeleuuringud tähendavad inimese tähenduse loomise ja edastamise viiside uuringuid reaalses situatsioonis või tekstide vahendusel.

Suhtluslikkus ja kehaline kogemus on inimesele olnud tähtsad kogu mõtestatud inimeksistentsi kestel. Meid ümbritsevat ruumi õpib inimene läbi liigutuste. Korduvad liikumismustrid leiavad kehastununa koha inimese taju andmetes. Taju, mälu ja keel moodustavad osa inimese kognitsioonist. Juhtivaid mälu-uurijaid Endel Tulving on öelnud, et mälu detailsus on seotud kehalise liigutusega. See, mis eristab inimest kogu ülejäänud loomariigist, on E. Tulvingu järgi meie autobiograafiline mälu (Allik, Tulving 2003). Keele, taju ja mälu seosed tulevad esile näiteks liigutuse kaudu.

Inimese maailmakäsitus, maailmapilt, kujuneb konkreetses sotsiokultuuris. Inimese eneseteadvus avaldub nt tema aja- ja ruumikäsituses, suhtumises õigusesse ja vabadusse, töösse, omandisse, rikkusesse ja vaesusesse, suhtumises surma ja religiooni. Aeg ja ruum on maailma eksistentsi määravad parameetrid ja inimliku kogemuse põhivormid. Seega on inimese teadvuse määravad kategooriad väljendatud selliste mõistete kaudu nagu aeg, ruum, muutumine, põhjus, saatus, arv, osa ja terviku suhe (Gurevitš 1992). Need universaalsed mõisted on igas kultuuris omavahel seotud ja moodustavad koos omamoodi maailmamudeli - see on võrgustik, mille vahendusel inimesed tajuvad tegelikkust ja ehitavad maailmapildi oma teadvuses. Seega juhindub inimene oma teadvuses ja tegevuses ühtedest või teistest maailmapildi põhikategooriatest. Nende tõlgendamisest sõltub palju tema 
enese, teda ümbritsevate sotsiaalsete gruppide ja kogu ühiskonna käitumises. Need kategooriad on kätketud keelde, aga samuti teistesse märgisüsteemidesse (kunsti, teaduse, religiooni keeltesse) ja mõelda maailmast nende kategooriateta on niisama võimatu nagu mõelda väljaspool keele kategooriaid.

Keelekasutus uurimisvaldkonnana moodustab tänapäeval osa interdistsiplinaarsetest uuringutest, kuhu kuuluvad vestlusanalüüs (ingl conversational analysis), diskursusanalüüs (discourse analysis), mitmekeelsuseuuringud, teise keele omandamine, antropoloogia, mikrosotsioloogia jm. Interdistsiplinaarsus on ühelt poolt avanud uued tahud keelekasutuse uurimises, kuid teisalt on keeleuurimise võimalused ise avardunud tänu lõimumisele teiste distsipliinidega ning uute tehnoloogiate arendamisele ning rakendamisele.

\section{Keelekasutus suhtluses}

Normaalne keelekasutus käitumiskompleksi osana sisaldab nii verbaalse kui mitteverbaalse ${ }^{1}$ aspekti. Teise maailmasõja järgseid verbaalse kommunikatsiooni uuringuid mõjutasid tugevasti Noam Chomsky seisukohad keelest. Teadmisel, et keelekasutaja on võimeline esitama lõpmatu hulga tähenduslikke lauseid, oli suur mõju verbaalse käitumise analüüsile, kuid see suurendas distantsi verbaalse ja mitteverbaalse kommunikatsiooni uuringute vahel. Nüüdseks on juba ammu leitud, et nii verbaalne kui ka mitteverbaalne kommunikatsioon on suhtlusprotsessid, milles saatja edastab infot, mis kodeeritakse märkidesse või teadetesse erinevates kanalites vastuvõtja jaoks, kes dekodeerib märgid infoks. Kuigi teateid ei edastata ei ainult verbaalselt ega ainult neljasilmavestlustes, on terminid kõneleja ja kuulaja kasutusel sünonüümselt terminitega saatja ja vastuvõtja.

Lähtudes üldiselt tunnustatud inimkäitumise uuringutest, võib kommunikatsioonis eristada kolme liiki infot: info kognitiivsuse kohta, motivatsiooniline info ja kõneleja tundmuslikud seisundid (Fiske 1990). Üldiselt on kognitiivne seisund see, mida kõneleja parajasti mõtleb; motivatsiooniline seisund vastab eesmärkidele, mida kõneleja tahab saavutada - see, mida ta kavatseb; ja tundmuslik seisund vastab tema tundmuste füsioloogilisele astmele. Seisundid muutuvad pidevalt ja on üksteisest sõltuvad. Kognitiivsed seisundid võivad näiteks tekitada tundmuslikke seisundeid ja vastupidi. Kognitiivsete seisundite uurimine viib ka küsimuse juurde, kuidas meie teadmised maailmast on esindatud mälus ja kuidas me nende teadmistega suhtleme keele kaudu. Motivatsioonilised ja tundmuslikud seisundid võivad olla aluseks meie mõnele ideele või mõttele. Kanalid, milles info kodeeritakse inimestevahelises suhtluses, on vastavuses inimeste meeleorganitega. Käitumine või signaalid on vaid märgid niivõrd, kuivõrd nad kannavad infot kõnelejalt kuulajale.

\footnotetext{
1 Siinjuures oleks sobiv märkida, et tänaseks ei seo uurijad žeste enam mitteverbaalse kommunikatsiooni mõistega. Adam Kendon on sellekohase märkuse teinud S. Tenjesele tema doktoridissertatsiooni arvustuses (Kendon 2001: 1). Ka David McNeill ütleb: "Sagedasem viga on võrdsustada žeste mitteverbaalse kommunikatsiooniga. Žesti üks tähendus on tõesti mitteverbaalne, s.t žesti esitatakse kätega, käsivartega, peaga, jalgadega ja isegi kogu kehaga ning mitte kõne jaoks spetsialiseerunud artikulatoorse aparaadiga. Siiski kasutatakse terminit mitteverbaalne kommunikatsioon tavaliselt .. tähenduses .. kui semioosise kolm nurka: regulatsioon, representatsioon, ekspressioon .. Seega, traditsioonilises tähenduses ei ole žest mitteverbaalne kommunikatsioon. Žest on keele osa, s.t verbaalse kommunikatsiooni osa." (McNeill 1999: 5)
} 


\section{Meetodi järjepidevuse hoidjad}

Indiviidide ja gruppide vaheliste tegevuste, reaktsioonide ja käitumise uuringute aluseks on lihtne fakt, et kõnelemine on sotsiaalne tegevus. Üks esimesi, kes inimese käitumise uurimise meetodeid kombineeris, oli Poolas sündinud briti antropoloog Bronislaw Malinowski (1884-1942). Oma uurimistööde käigus märkas ta, et oluline oli mitte ainult küsitleda uuritavaid, vaid ka kuulata ja vaadata, kuidas nad omavahel igapäevaselt suhtlevad. B. Malinowskilt pärinevad kaks keele etnograafilise teooria põhimõistet: 1) situatsioonikontekst (ingl context of situation) ja 2) vaade keelele kui tegevusviisile (language as a mode of action) (Duranti 1999: 215). B. Malinowski märkas ka üsna ruttu, et ütluste sõnasõnaline tõlge või keeleväljendite otsene tõlge ei aita uurijal konkreetsest keelekõnelejast aru saada - vaja on mõista situatsiooni, milles neid sõnu kasutati. Nii pakkuski ta välja situatsioonikonteksti mõiste. Mõiste töötati välja keeleuurimiseks, kuid ei sobinud surnud keelte (nt ladina või sanskriti) jaoks. Nii aga saigi alguse keele etnograafiline teooria. Kirjutades oma teose "Coral Gardens and Their Magic" ("Korallaiad ja nende maagia”) teist osa (1935), jõudis B. Malinowski (1978 [1935]: 7) järeldusele, et keele peamine funktsioon pole mitte mõtte väljendamine ega mentaalsete protsesside dubleerimine, vaid keele roll on pigem olla aktiivne pragmaatiline osa inimese käitumises. 21. sajandil võime öelda, et need ideed on leidnud oma interdistsiplinaarse pinnase Euroopas (nt Levinson 1983) ning isegi Malinowski verbaalse akti mõiste (1978 [1935]: 9) on mõjutanud John Austini kõneakti tulekut.

Ka George Herbert Mead on andnud panuse vestlusanalüüsi alustesse. Temalt pärineb sümbolilise interaktsionismi mõiste, mille järgi inimeste isesus (ingl self) on sotsiaalne produkt (Blumer 1969). Ideed arendasid edasi tema õpilased Herbert Blumer jt. Otseselt on mõistega seotud sotsiaalne interaktsionism (Mead 1934, 1938). Vestlejad on sotsiaalse ühenduse (ingl community) liikmed, kes jagavad selle ühenduse reegleid ja kokkuleppeid. See võimaldab neil vestlustest osa võtta. Kõnelejad ja kuulajad peavad vestluse käigus pidevalt aimama üksteise reaktsioone ja kavatsusi ning oma käitumist vastavalt modifitseerima. See on võimalik, kuna interlokuutorid ehk vestluse osapooled teavad, et nad mõlemad on konkreetse sotsiaalse ühenduse liikmed, jagades selle ühenduse sotsiaalsete institutsioonide reegleid. Üks selline sotsiaalne institutsioon on õigussüsteem, teine on keel. Vestluse osapooled teavad keelereegleid ning nende kasutust. See annab kõnelejatele ja kuulajatele võimaluse aimata üksteise eesmärke, oletada üksteise reaktsioone ning järjestada neid, et teha panus koostööle. Kõnelejad ja kuulajad arvestavad üksteisega kui nn üldistatud teisega (Mead 1934, 1938), nii et nad võivad aimata üksteise reaktsioone ja ära tunda üksteise intentsioone. Seeläbi on võimalik nendevaheline kommunikatsioon.

Näiteks kõneleja ütleb: "Mul on janu." Kuulaja, kasutades keelereegleid ja teadmisi keelekasutusest ning teades, et mõlemad neid mõistavad, võib omistada kõnelejale kindlaid intentsioone. Kuulaja võib eelneva lausungi puhul omistada kõnelejale intentsiooni, et too soovib kuulajale selgeks teha oma joogisoovi. Veelgi enam - kindlas kontekstis ja situatsioonis (nt jalutades mööda kohvikust) ning keelereeglitest, mis on mõlemale teada, võib kuulaja eelnevast lausest teha järelduse, et kõneleja soovib peatuda ja pisut juua. Käsitlusest on tänapäeval välja kasvanud laialt kasutatav mõiste ühiselt jagatud teadmised, mis põhineb Herbert Clarki koostööprotsessi mudelil, kus informatsioon jagatakse interaktantide vahel, kes 
mõjutavad üksteist, omades ühist alust (ingl common ground) või ühiseid teadmisi ja uskumusi (Clark 1992).

1960. aastate nn kognitiivse revolutsiooni ajal tundus B. Malinowski tugevalt biheivioristlik suund lausa anakronistlik: oli peen rääkida mind'ist kui arvutist jms. Selle vooluga ei läinud kaasa need, kes uurisid kehaliigutusi. Sest kui keha funktsioon ja kõnelemise koht suhtluse ajal on oluline keeleliste praktikate jaoks, on järelikult oluline ka keeleline käitumine situatsioonis. Üks tuntumaid selle suuna esindajaid on Charles Goodwin (1981 jm), samuti ka Adam Kendon, David McNeill jt. Tuleb märkida, et kõik nad uurivad käežeste, kuid C. Goodwin suundus vestlusanalüüsi meetodeid kasutades situatsioonide analüüsi juurde, A. Kendon ja D. McNeill on olnud - kuigi erinevalt - kõne ja žesti seoste uurijad.

Kuigi J. Austin oli loonud süstemaatilise teooria keelest kui tegevusest (Austin 1962), eitas lingvistika vestluse uurimist pikka aega. Lingvistide jaoks oli konversatsioon liiga segane asi (ingl too messy, Duranti 1999: 245), täis valesid algusi, ebakorrektset grammatikat, mis ei andnud neile võimalust grammatikat sobival viisil analüüsida. Seda, et analüüs võiks minna väljapoole grammatikat, ei peetud lingvistikale sobivaks. Liigutuste uurimine ja välitööde tegemine on alati olnud peamiselt antropoloogide valdkond.

Kuigi konversatsioonilised muutused olid alati olnud olulisteks informatsiooniallikateks igaühele, keda huvitasid kultuurilised praktikad ja sotsiaalne organisatsioon, ei saanud konversatsioon per se uurimisobjektiks enne 1970ndaid. See toimus tänu väikesele sotsioloogide grupile eesotsas Harvey Sacksi ja Emanuel Schegloffiga, kes keskendusid konversatsioonilistele muutustele. Oma programmi nimetasid nad vestlusanalüüsiks (ingl conversation analysis), et rõhutada fakti, kuidas vestlus võib olla sotsioloogilistes uuringutes tõeline uurimisvaldkond. Nende jõupingutuste tõttu said konversatsioonianalüüsi uuringud olulisteks nendele, keda huvitas keele kasutamine sotsiaalses interaktsioonis.

Vestlusanalüüs on teatava kaarega lingvistikas jõuliselt edasi liikunud. Kaare all mõtleme seda, et vestlusanalüüs on tulnud sotsioloogide juurest tagasi keeleteadlaste juurde, kellel on huvi samade probleemide vastu, kuid samas soov rohkem arvestada keeleliste aspektidega.

21. sajandi alguses võime öelda, et vestlusanalüüs on meetod, mis lubab suhtlus- ja käitumissituatsioone analüüsida ning seda meetodit saab kasutada diskursusuuringutes.

\section{Vestlusanalūūs ja diskursusanalūūs}

Uuringutes keele kasutamisest vestluses on võimalik leida kaks erinevat suunda. Need on omavahel seotud eri distsipliinide kaudu, mis neid uurimusi on suunanud.

Esimene distsipliin, milles vestlusi uuritakse, on sotsioloogia, ja konkreetselt just see sotsioloogiaharu, mis tegeleb sotsiaalse interaktsiooniga sotsiaalse ühenduse üksikute liikmete vahel. Olulise panuse sotsioloogilistesse uuringutesse tavavestluses on andnud uurijad, kes kuuluvad etnometodoloogia koolkonda. Tuntumad esindajad on siin Harold Garfinkel, Harvey Sacks, Emanuel A. Schegloff, Gail Jefferson ja John Heritage. Etnometodoloogid on huvitatud implitsiitsetest teadmistest, meetoditest ja protseduuridest, mida sotsiaalse ühenduse liikmed kasutavad ja mille kaudu suhtluses osalejad määravad, interpreteerivad 
ja edastavad tähendusi oma igapäevases tegelikkuses. Etnometodoloogide jaoks on olulised sotsiaalsed tegevused, esmased valdkonnad, milles luuakse vestlejate sotsiaalne maailm. Etnometodoloogid loodavad vestlusi uurides avastada märke toimimisviisidest, mida osapooled oma sotsiaalseteks interaktsioonideks kasutavad, ja viise, milles suhtlejad omavahel määratlevad sotsiaalset situatsiooni vestluses. (van Rees 1992: 19)

H. Garfinkel leidis, et sotsiaalsete nähtuste uurimine kaasamata inimese keelekasutust on kasutu. Ta lülitas vestlusanalüüsi meetodi uuringutesse inimese ja sootsiumi vahekorra küsimuste lahendamisel ning hakkas California ülikoolis lugema vestlusanalüüsi kursust. Tänastes sotsioloogiauuringutes on see meetod kindlalt juurdunud. ${ }^{2}$ Vestlusanalüüs on üheks meetodiks, kuid uurimisobjektiks on inimene, kes reaalses situatsioonis käitub, sealjuures suhtleb nii kõne- kui käeliigutuste kaudu ning näoilmetega, kogu kehaga. Inimene suhtlebki kompleksselt edastab tähendusi erinevate kanalite/modaalsuste kaudu.

Teine distsipliin tavavestluse uurimiseks on lingvistika alldistsipliin sotsiolingvistika. Selle teadusharu olulisemad esindajad on nt William Labov, Malcolm Coulthard, John McH. Sinclair ja William Edmondson. Sotsiolingvistid on alati olnud huvitatud tavalisest, igapäevasest keelekasutusest, kuid alles 20. sajandi lõpupoole hakkasid nad huvi tundma rohkem keele variatiivsuse vastu sotsiaalsete makrovariaabluste raames. Variatiivsusi esindavad sugu, etniline taust, klassikuuluvus ja vanus. Samuti on sotsiolingviste 20. sajandi lõpul hakanud huvitama konversatsioonitemaatika. Konkreetselt on vestluste sotsiolingvistilised uuringud keskendunud seostele keele lausungite vormi ja funktsiooni vahel ning viisidele, kuidas lausungeid vestlustes kombineeritakse.

Selliseid uuringuid, mida viivad läbi sotsioloogid, nimetatakse sageli konversatsioonianalüüsiks; uuringuid, mille eesotsas on peamiselt lingvistid ja sotsiolingvistid, nimetatakse diskursusanalüüsiks. Need kaks uurimissuunda erinevad nii oma eesmärgilt kui meetodilt.

Konversatsiooniuurijad peavad oma eesmärgiks anda interaktsiooniliste protseduuride kirjeldus, mida vestluse osapooled kasutavad, kui nad moodustavad ja interpreteerivad kaaspanuseid vestlusesse. Uurija kirjeldab, kuidas interaktsioon iga vestleja jaoks samm-sammult areneb. Ta väldib sihilikult eelnevalt omaksvõetud teoreetilisi seisukohti. Erinevused tuuakse esile vaid siis, kui empiiriliste andmete alusel on selgeks saanud, et need on esitatud vestlejate poolt. Üks omaksvõetud seisukoht on nn. vaatluslik naiivsus (van Rees 1992: 20): iga detail võib osutuda tähtsaks. See on ka üks põhjusi, miks nad nii palju kui võimalik töötavad lindistuste "musta" materjaliga või nende võimalikult täpse transkriptsiooniga.

Lühidalt olulisemad pidepunktid vestlusanalüüsi temaatikast:

1) vestlusanalüüs arenes välja H. Sacksi töödest;

2) vestlusanalüüs uurib keelt kui sotsiaalset tegevust;

3) vestlust interaktsioonis peetakse süstemaatiliselt organiseerituks ja korrastatuks;

4) esmased andmed uuringuteks on loomulikult esineva interaktsiooni audiolindistused (ja seal, kus see on vajalik või sobiv, videolindistused). Transkriptsioonid abistavad audio-/videoanalüüsi materjale; 
5) transkriptsioonisüsteem esitab igapäevavestluse n-ö segaduse detailse iseloomustuse, keskendudes kõne esitamisele ja vooruvahetuse ${ }^{3}$ organiseerimisele. (Wooffitt 2006: 13)

Mõiste, mida palju kasutatakse, aga mida on keeruline defineerida, on diskursus (ingl discourse). Diskursus on eri autoritel pisut erineva sisuga täidetud mõiste ja mõnedel neist pole midagi pistmist keelega. Nt rassilise diskrimineerimise diskursus on seotud pigem ideoloogiate ja uskumuste süsteemidega kui konkreetsete keeltega, veinidiskursus ${ }^{4}$ hõlmab lisaks veininduse tootmisprotsessides ja degusteerimises kasutatavale erisõnavarale ka alldiskursusi nagu pudelisildi tekst ja disain ning ristub muude diskursustega (nt triipkoodil kaubandusliku diskursusega).

Diskursust võib määratleda kui situatiivset keelekasutust (He 2003: 429) nii kirjalikes kui suulistes tekstides. Esiteks sisaldab ta rohkem kui ühte lauset ja on ses suhtes paralleelmõiste tekstile. Nii sotsioloogide kui keeleteadlaste jaoks seostuvad diskursusuuringud esmalt just tekstiuuringutega. Aga lisaks tekstile haarab diskursus ka relevantseid konteksti komponente: kõigepealt kõneleja ja kuulaja relevantseid aspekte alustades nende eesmärkidest, eeldustest, taustteadmistest jne ning lõpetades suhtlejate sotsiaalsete parameetritega. Peale selle kuuluvad siia veel suhtlussituatsiooni parameetreid: kas räägitakse kohtus või kohvikus jne. Ülevaatlikult on diskursuseuuringute teemat käsitlenud Teun van Dijk (nt 1997: 1-34).

Kui vestlusanalüüs on uurimismeetod, siis diskursusanalüüsi võib käsitleda uurimisvaldkonnana. Diskursusanalüüs vaatab, kuidas inimestevaheline vestlus on üles ehitatud. Varasemas etapis uuriti tavaliselt dialoogi ja analüüsiti seda, hiljem lisandus situatiivne analüüs. Kui diskursuse-uurijate poolt vaadata, siis kuulub siia ka pragmaatika. ${ }^{5}$ Vaadeldakse suhtlusstrateegiaid, suhtlussituatsiooni kui tervikut, mitte ainult kõnet; jälgitakse konteksti. Vaadeldakse vooruvahetust, nt kuidas keel lubab katkestada repliiki. Uuritakse, millal ja kuidas saab inimest katkestada jne. Eelkõige Ameerikas on uuritud telefonikõnesid õnnetuste puhul politseisse ja kiirabisse. Need on olukorrad, kus tuleb kiiresti anda maksimaalselt infot. Ka Eestis on telefonivestluste uurimine olnud tähelepanuväärne, sellega on mitme aasta jooksul tegelnud Tiit Hennoste uurimisrühm (vt nt Hennoste 2003a, Hennoste 2003b, Rääbis 2000, 2002). Võib arvata, et vestlusanalüüsi meetodi populaarsus ja mõju Soomes lõi tänu professor Auli Hakulise töödele (eesti keeles vt Hakulinen 1986) esmased võimalused teemaga tutvumiseks ning mõjutas Eesti suhtlusuuringute tegevuse algust. Täna on Soome humanitaar- ja sotsiaalteadlased, kes tegelevad diskursus- ning vestlusanalüüsiga, koondunud mitmete ülikoolide juurde üle Soome. Tuntumad neist on Helsingi, Tampere, Jyväskylä ja Oulu grupid, kuid uurijaid leidub ka näiteks Kajaanis. ${ }^{6}$

Diskursuse analüüsijad seavad oma eesmärgiks kirjeldada vestluste ülesehituse põhimõtteid. Nad otsivad reegleid, mis võiksid selgitada keele lausungite edukust vestluses. Lingvist uurib vestlust mitte vestlejate seisukohast, kelle jaoks interaktsioon areneb samm-sammult, vaid kui eemalseisja, kes analüüsib vestlust kui tervikut siis, kui see on läbi. Oma analüüsis kasutab ta sageli analüütilise raamistikuna kõneaktiteooriat. Eelkõige on ta huvitatud seosest keele lausungite formaalsete joonte

\footnotetext{
Kõnevoor on intuitiivselt määratletud dialoogiüksus, ühe kõneleja jätkuv häälesolek.

4 Näide pärineb Raili Pöldsaarelt doktoriseminarist "Suhtlusandmete analüüs ja analüüsi meetodid" (26.11.2008)

5 Kuigi me nimetasime pragmaatikat ja keelefilosoof J. Austinit, jääb pragmaatika käsitlus sellest artiklist välja.

Näeme pragmaatikas piiritletud keeleteaduslikku uurimisvaldkonda, mis hõlmab eelkõige kõneaktide teooriat ja

küsimuse-vastuse uuringuid, sealhulgas küsimise erinevaid viise ning viisakusteooriaid, ega sisalda piisavalt süsteemset meetodit suhtlus- ja käitumissituatsioonide analüüsiks.

6 Teema aktuaalsuse kohta Põhjamaade ülikoolides ja selle seotust Tartu Ülikooliga vt ka

http://www.placeme.hum.aau.dk/ (30.09.2008).
} 
ja kõneaktide vahel, mida võib esitada koos nende lausungitega konkreetsel ajal vestluses. Samuti on ta huvitatud kõneaktide järgnevusest ja sellest, kui suure hulga kõneaktide puhul võib erinevaid kõneakti järgnevusi kirjeldada edukalt moodustatutena. Spontaanne kasutus, mis sisaldab materjali analüüsi jaoks, "puhastatakse" tavaliselt neist elementidest, mis arvatakse olevat analüüsi jaoks ebaolulised, nagu valed algused, pausid, osalised kattumised jms. Mõnikord töötab uurija omaenda väljamõeldud näidetega (nn tugitooliteadus). Peamine on sõnaselgelt esitada ja testida uurija intuitsioone, mis puutub seosesse keele lausungite vormi ja funktsioonide vahel, ning reeglite suhtes, mis määravad nende esitamise korra.

Lühidalt olulisemad pidepunktid diskursusanalüüsi temaatikast:

1) diskursusanalüüs on kasvanud välja teaduslike teadmiste käsitlemisest sotsioloogias (vt nt Wooffitt 2006);

2) ta rajas kõrvalharu teadlaste tegevuste realistlike seletuste juurest teaduslike selgituste uurimise praktikate juurde;

3) diskursusanalüüs väidab, et kuna keelt kasutatakse varieeruvalt, siis uurimisel konstrueeritakse selgitused deskriptiivsete võimaluste hulgast, selgitused on tihedalt seotud kontekstiga, kus nad esile tuuakse ja funktsioonidega, mida nad esitavad (Wooffitt 2006: 18).

Mõlemal suunal on arvestatavaid tulemusi suhtluse uurimises.

\section{Kommunikatiivse situatsiooni dūnaamilisus: tähendus luuakse suhtluses}

Suhtlussituatsiooni käsitlemisel on oluline tähele panna suhtlusvõime arenguid inimesel. Peamisteks mehhanismideks sümbolilise keele arengul on paljud uurijad pidanud ikoonilisust ja analoogiat (vt nt Place 1998, Koch 2001, Sinha 2001, 2005, Itkonen 2005). Ikoonilisus võib olla inimese evolutsiooni käigus arenenud aluseksolev võime keelelisteks modaalsusteks. Ikoonilisus kui koopiategemise võime on üks võimeid kommunikatsiooni evolutsioonis, mis võis areneda ja mitmel erineval korral siseneda suhtlusvõimete ja -viiside arengusse. Keele üleüldine esmane väljund võis olla pantomiim, hiljem kondenseerub pantomiim žestiks ja lõpuks võtab hääleline žest ehk foneemide kaudu esitatud keel juhtimise üle (Koch 2001). Ameerika viipekeele uuringud, ja Hiina piktogrammide arengu ajalugu näitavad, et häälelisest kõnest sõltumatu lingvistilise kommunikatsioonisüsteemi arengus on kõige varasemad märgid reeglipäraselt ikoonilised. Nad imiteerivad selle objekti visuaalset välimust, mida nad kujutavad. Kõikidel juhtudel oli näha märgisüsteemi arengutendentsi liikuda eemale ikoonilisusest ja suunduda arbitraarsete sümbolite poole, millel pole sarnasust sellega, mida nad esindavad. (Place 1998: 2)

Suhtlussituatsioonis on koos kõne oma eripäraga, nt intonatsiooniga, näomiimika ja spetsiifilised käeliigutused. Käežeste on mitmesuguseid, aga ikoonilised on äärmiselt levinud. Ikoonilises žestis on kindel hulk samakujulisust (isomorfismi) žesti kuju ja entiteedi vahel, mida selle žestiga väljendatakse. Seda tüüpi žestidel on suhteliselt läbipaistev vormi-funktsiooni seos, neil on kommunikatsioonis oluline roll (Kita 2000: 162).

Žestid koos visuaalse ja verbaalse komponendiga toovad esile liigutuse funktsionaalse tähtsuse või tähenduse inimkommunikatsioonis. Varasemad uuringud 
on juba näidanud, et käežestid on oluliseks faktoriks tähenduste ja kavatsuste edasiandmisel (vt nt Kendon 1980, Kendon 1986, Goodwin, Goodwin 1986, Calbris 1990, McNeill 1992, Bavelas 1994, Bavelas jt 1995, Cienki 1998, Cassell jt 1999). On näiteks teatud vähemärgatavad käeliigutused, mis kaasnevad ainult dialoogis ja mida mõlemad kõnelejad tajuvad ning millele nad ka reageerivad. Selliseid žeste nimetatakse vestlusžestideks (Bavelas jt 1995), nt käe ringitav liigutus, millel on kontekstist olenevalt erinevaid nimetusi, aga eelkõige võiks ta nimi eesti keeles olla aita leida õige sõna (nt lauses Mis selle kuti nimi oligi, kes ..) (selle kohta vt ka Tenjes 2002). Käeliigutuse kommunikatiivsed funktsioonid tulevad esile eelkõige kujutamise, suuna või referendile viitamise kaudu. Ka muudest kehaliigutustest võib rohkesti infot kätte saada, võrreldes pelga kõnelise situatsiooniga (nt laseb naine oma sigaretile tuld pakkuda, tõstab jala üle põlve jne).

Multimodaalse suhtluse uuringute kaudu saabki uurida kahte omavahel seotud tasandit: inimese keelekasutust mingis kommunikatiivses situatsioonis ning kommunikatiivse situatsiooni dünaamikat. Suhtluse ja keelekasutuse sügavamaks mõistmiseks on vajalikud just multimodaalse interaktsiooni struktuuriuuringud, mis analüüsivad seoseid inimese kognitsiooni ja suhtlusvahendite repertuaari valiku vahel ning suhtlusstrateegiate valikuid mõjutavaid sotsiaalseid ja kultuurilisi aspekte. Multimodaalses suhtluse analüüsis vaadeldakse erinevate kommunikatiivsete vahendite kasutamist suhtluse käigus. Nende kasutamisega loovad suhtlejad tähendusliku kommunikatiivse situatsiooni.

\section{Videolindistused suulise keeleainestiku kogumise meetodina}

Suhtluse erinevad komponendid sotsiaalses interaktsioonis lubavad keele kasutamist vaadelda detailsemalt, kas läbi erinevate keeletasandite või läbi kehastunud interaktsiooni. Keelekasutuse uuringud, kus keelekasutajad suhtlevad ning üksteist ja oma tegevusi komplekses multimodaalses keskkonnas (ka virtuaalses) mõjutavad, nõuab uurimiseks videoainestikku. Keeleainestiku kogumine videokaamera(te) abil, videoainestike töötlus ja analüüs on kaasaegsete interaktsiooniliste keeleuuringute asendamatu instrument ning esmane nõue detailse ning mitmekülgse uurimisainestiku saamiseks (Scollon, Scollon 2001, Heath, Hindmarsh 2002, Goodwin 2003, 2007).

Videoainestikud on multimodaalsed ning multidimensioonilised, markeerides kommunikatsiooni nelja põhiaspekti: keelekasutus, situatsioon, aeg ja ruum. Mitteverbaalse suhtluse uurimise kõrval on videoainestike kasutamisest saamas või saanud lahutamatu tööriist näiteks mitmekeelse suhtluse (nt Lehtonen 2004) või lapsekeele uurimises (nt Hassinen 2002). Suhtluse uurimisel, kus mõni suhtlusmodaalsus - nt kõne - on takistatud, tuleb videolindistuste kasulikkus eriti esile. Kui kõnepuude korral pole võimalik midagi diktofoniga lindistada, on videolindistuse kaudu muude suhtluskomponentide kasutamine jäädvustatud ning analüüsitav.

Brigitte Jordan ja Austin Henderson (1995) jagavad sotsiaalse interaktsiooni ainestikud kahte tüüpi: otsene vaatlus (ingl direct observation) ja taastatud sündmus (reconstructing event) ehk toimunu uuesti jutustamine. Videoainestikud kuuluvad otsese vaatluse hulka. Videomaterjal tagab suurema metodoloogilise 
objektiivsuse, mis konversatsioonianalüüsi, aga ka diskursusanalüüsi puhul on oluline nõue.

Videoainestikul on mitmeid eeliseid traditsiooniliste suulise kõne ainestiku kogumise meetodite ees. Videokaamera jäädvustab kommunikatsiooni terviklikkuse: ühelt poolt sõnalise osa ehk suhtluse kõneosa, teiselt poolt aga žestide, viibete, asendite osa ning ruumilise asukoha ja liikumise. Niisiis paljastab videoainestik uuritava ilmingu sellisena nagu see on, nii verbaalsest kui visuaalsest küljest, nii verbaalne kui mitteverbaalne kommunikatsioon on alati nähtaval kohal. Videosse salvestatud ainestik sisaldab rohkem konteksti uuritavast materjalist kui diktofonilindistused, ja tänu võimalusele videolinti korduvalt vaadata on kontekst kogu aeg n-ö kohal. (Vuokila-Oikkonen 2002: 72)

Vähetähtis ei ole ka asjaolu, et videoainestik võimaldab mitme informandi suhtluse samaaegset ning mitmetasandilist uurimist. Uurides suulist kõnet audioainestiku põhjal, jääb osa tegureid paratamatult välja. Videoainestiku rakendamine aitab meie hinnangul paljudele varem peitujäänud küsimustele vastuseid otsida ja leida. Videoainestiku eeliseid näeme selles, et ta võimaldab

1) uurida interaktsiooni mitmekülgsust;

2) uurida suhtlust tervikuna (kõne, žestid, näoilmed, kehaasendid jne);

3) jäädvustada situatsiooni ajas ja ruumis;

4) analüüsida kommunikatsiooni selle "nähtavas" kontekstis;

5) uurida detailselt sotsiaalset interaktsiooni.

Hoolimata videomaterjali loetletud eelistest, ei ole videoainestiku kogumine ning videomaterjaliga töötamine uurija jaoks kindlasti probleemitu. Päivi VuokilaOikkonen (lähemalt vt 2002: 72-73) nimetab videoainestiku uurija suurimaks väljakutseks mitmekülgsest ja rikkalikust materjalist uuritava ilmingu jaoks oluliste tegurite eristamist. Analoogselt mis tahes muude empiiriliste uuringutega ei ole ka videoainestike puhul võimalik vältida üldisi keeleainestike kogumise probleeme. Iga uurimisprotsessi võib pidada erinevate kohtumiste sarjaks, mis mõjutavad ühel või teisel viisil kõiki osapooli (Vuorinen 2001: 243). Uurija mõju ei ole kuidagi võimalik vältida. Uurija mõju lindistussituatsioonile nimetatakse vaatleja paradoksiks (ingl Observer's Paradox, Labov 1972: 209) ning sellega puutub kokku iga keeleainestiku koguja. Nii informant kui intervjueerija muudavad alateadlikult oma käitumist ning keelekasutust, soovides käituda "korralikult" ning uurijale meeldida. Seepärast ongi põhjendatud konversatsiooniuurijate püüd koguda materjali loomulikes tingimustes ning nad käsitlevad ka uurimisgrupi liikmete endi käitumist kui veel üht andmete liiki, mida peab edaspidi arvesse võtma (Duranti 1999).

Vestlusanalüüsi esmane uuendus oligi lihtne metodoloogiline nõue, et uurimisobjektidena peab kasutama võimalikult loomulikult toimunud vestluste lindistusi, s.t vestlusi, mis toimusid juhuslikult, mida uurijad ei olnud planeerinud ega kontrollinud. See oli vastupidine materjalile, mida saadi etnograafiliste intervjuude ajal või hiljem katseolukordades, kus inimestel paluti mingit rolli täita.

Keeleainestiku kogumist mõjutavad ka ainestiku kogumise vahendid, nt diktofon või videokaamera. Ideaalses töösituatsioonis peaks lindistav diktofon või filmiv videokaamera olema kui mööbliese, mille olemasolu jääb märkamatuks nii intervjueeritavale kui intervjueerijale. Et keeleainestiku kogumine õnnestuks, on uurija ülesandeks panna intervjueeritav ennast lindistusolukorras vabalt tundma, et informandi keelekasutus oleks ka lindistussituatsioonides niisugune nagu tava- 
situatsiooniski (vt nt Labov 1972: 61). See metoodika kuulub eelkõige sotsiolingvistika uurimisvaldkonda.

Videoainestike kogumine ning ainestiku analüüsimine on töömahukas ja aeganõudev mitmeetapiline, loogilist järgnevust eeldav tööprotsess, mis koosneb järgmistest etappidest: 1) ainestiku kogumise meetodi ja informandi valik; 2) tehniliste küsimuste lahendamine (kaamera, filmija, aeg ja ruum); 3) filmimine; 4) analüüsitavate lõikude valik; 5) videolõikude visuaalne, nn väline analüüs; 6) lõikude litereerimine ning 7) ainestiku detailne analüüs vastavalt uurimiseesmärkidele. Uurimiseesmärkide suhtes võime väita, et just loomulikus situatsioonis jäädvustatud suhtlussituatsiooni materjal annab ise aluse, millest kasvavad välja uued ja relevantsed tulemused.

\section{Materjali esitamine}

Oleme valinud suhtlussituatsiooni dünaamilise dimensiooni esiletoomiseks katkendi filmitud videomaterjalist. Videolõigu litereeringule on lisatud selle analüüs. Detailne vestlusanalüüs baseerub G. Jeffersoni süsteemil (Sacks jt 1974) ning Paul ten Have $(2004,2006)$ töödel. Materjal keskendub 17-aastase, tavaarusaamade kohaselt kõnetu tütarlapse suhtlusele. Väidame, et kommunikatiivses situatsioonis saab tähendus tekkida ka siis, kui ühe osapoole kõnekeelelised võimed on piiratud. Tütarlapse diagnoos on 13. kromosoomi mosaiikne trisoomia ehk Patau sündroom. Patau sündroomiga kaasneb alaalia ehk düsfaasia ${ }^{8}$, kuigi kuulmine on normis. Kuna Patau sündroomiga inimesed on sageli sündides surnud või elanud väga lühikest aega, pole selle diagnoosi kohta väga palju informatsiooni kogu maailmas. Seda hinnatavam on antud materjali analüüsi võimalus.

Analüüsimiseks valitud näide on salvestatud informaalses situatsioonis vestluspartnerite kodus.

Aeg: 16. juuni 2007, umbes kell kaks päeval.

Osalejad: 17-aastane tütarlaps, tema vanem vend, nende ema.

Osalejate asetus: vend istub arvuti taga, õde seisab tema kõrval, ema seisab kaameraga 1,5 meetrit eemal ja filmib.

Salvestusvahendina on kasutatud ainult üht videokaamerat. Situatsiooni peamised osapooled on tütarlaps ja tema vend. Ema, kes salvestab situatsiooni kaameraga, osaleb abistavate küsimuste või kommentaaridega. Salvestussituatsiooni spetsiifikast tulenevalt jääb üks osapool, ema, kaamera taha, mistõttu on temalt salvestatud vaid kõnekeelne osa.

Vestluses osalejate markeerimisel on kasutatud lühendite süsteemi. Kuna kõnes mainitakse mitmel korral erinevaid eesnimesid, kasutatakse nende asemel peitelühendeid. Kõikide informantide anonüümsus on garanteeritud ning salvestusi kasutatakse osapoolte nõusolekul. Situatsioonis osalejad on tähistatud järgmiselt:

$$
\begin{aligned}
& \text { T - 17-aastane tütarlaps; } \\
& \text { V - tema vend; } \\
& \text { E - nende ema; } \\
& \mathrm{S}_{1} \text { - sugulane 1, 4-aastane tüdruk; } \\
& \mathrm{S}_{2} \text { - sugulane 2, 3-aastane poiss. }
\end{aligned}
$$

\footnotetext{
7 Patau sündroom ehk 13. kromosoomi trisoomia võib avalduda mosaiikvariandina. Sellisel juhul on mõnedel keharakkudel 13. kromosoomist 2 koopiat, mõnedel aga 3 koopiat. Seda sündroomi esineb suhteliselt harva (1:12 000 ...1:29 000) ja mosaiikset varianti on kirjeldatud ainult üksikutel juhtudel.

8 Alaalia ehk düsfaasia on peaaju koore kõnekeskuste orgaanilisest kahjustusest tingitud kõne arengu häire.
} 
Vaadeldavas vestluses soovib $\mathrm{T}$ teada, kus on $\mathrm{S}_{1}$ - 4-aastane tüdruk, väike sugulane. Sellisel teemavalikul on oma tagamõte. T teab, et $S_{1}$ on vanavanemate suvilas Pangodis. $T$ tahaks ise sinna pääseda, niisiis juhib ta jutu endale sobivale teemale.

(1)

1 T: öhö?

(( Kasutab viipeid ja hoiab vasakut kätt venna õlal, et $V$ talle kindlasti vastaks. Näitab eesti viipekeele viibet LAPS, s.t näitab käega inimese kasvu)) ((lausungi tõlge: Kus $\mathrm{S}_{1}$ on? või Mida $\mathrm{S}_{1}$ teeb?))

2 V: kodus on

3 T: [öhö?]

4 V: [mängib]

5 T: [öhö?]

6 E: näita T veel seda [märki]

7 T: [öhö?]

((Hoiab ühte kätt venna õlal, teisega viipab kaugusse. Vaidleb vastu, ütleb, et $S_{1}$ on ju Pangodis))

8 E: [ $\mathrm{S}_{1}$ või]

9 V: [pangodis või]

10 T: aa ((jaatusüneem))

$11 \mathrm{~V}$ : jah olime pangodis

12 T: öhö?

13 V: [käis] ujumas

$14 \mathrm{E}$ : [kas] $\mathrm{S}_{1}$ tuli tagasi ka või

$15 \mathrm{~V}$ : jaa

16 E: tartusse

$17 \mathrm{~V}$ : mängib $\mathrm{S}_{2}$-ga seal

18 T: iaa? ((Tõlge: siia. Näitab põranda poole, s.t kasutab viibet SEE KOHT SIIN))

19 V: siia.

20 T: aa ((jaatusüneem)) ((Kasutab uuesti viibet SIIN))

21 V: ma ei tea seda

22 T: AA-AAA (( tõlge: ahjaa, nüüd tuli meelde))

((Koputab endale vastu rinda, raputab kätt õhus ja võtab lõpuks sõrmedega ninajuurest kinni. Tõlge: mulle tuli meelde, et mina ka pidin Pangodisse minema))

$23($.

((Õde vaatab pingsalt vennale otsa ja ootab vastust: ta tahab ka Pangodisse pääseda, vend oleks see, kes ta sinna viiks.))

24 T: ühaäe? ((Tõlge: ühaäe on adapteeritud pühapäev, mis tähendab üldistatult ükskõik millist nädalapäeva $\rightarrow$ Mis päeval sa Pangodisse sõidad? Osutab vennale, sest küsimus on mõeldud talle.))

$25 \mathrm{~V}$ : homme võib-olla lähen jah

26 T: öhö?

27 V: aga võib-olla hoopis tõlgin

28 T: aua? ((Tõlge: silbiga aua tähistab kõneleja ennast $\rightarrow$ Mis mina homme teen? Osutab endale.))

29 T: emme ((Tõlge: kõnetab ema)) 
((Näitab eesti viipekeele viibet LAEV (kaks kätt kausikujuliselt ühte külge pidi koos), liigutab käsi endast eemale $\rightarrow$ Kas ma lähen laevaga sõitma?))

30 E: laevaga sõitma või

31 T: jah ((noogutab))

32 E: nojah memm planeeris seda et

$33 \mathrm{~V}:(($ naer $))$

34 T: eee memmu ((võtab telefonitoru))

35 E: et kui on hea ilm siis

36 T: ee-memmu-memmu ((Tõlge: Helistame vanaemale!))

((Hoiab telefonitoru käes, tahab vanaemale helistada.))

37 E: hakkad memmele helistama või

38 T: aa-aa ((jaatusüneem))

39 E: no V valib sulle numbri siis

\section{Materjali analūūs}

Vestluses avaldub T motiveeritus ja järjekindlus jutuajamise suunamisel. T suhtlemisvahendid on omavahel keerukalt kombineeritud ja allutatud ühele eesmärgile - ennast arusaadavaks teha. $\mathrm{T}$ kasutab suhtlemiseks eelkõige liigutuslikke vahendeid (žestid, näomiimika, kehaasendid), kuid tema eneseväljenduses esineb ka kõnekeelelisi elemente (adapteeritud emakeel, häälitsused, silbid). Tema keel koosneb seega auditiiv-verbaalsest ja visuaalsest poolest. Viibete ja žestide tähendusväljad on laiad ja sõltuvad konkreetsest kontekstist. Vesteldes tahab T küsimusi esitada eelkõige selleks, et vestlust talle soovitud suunas juhtida. Samuti ootab ta oma dialoogipartneritelt abi enda mõtete sõnastamisel, s.t täpsemal väljendamisel: ta soovib, et tema žestid sõnadeks dešifreeritaks, misjärel saab ta märku anda, kas "tõlkimine" õnnestus või mitte. Seda tüüpi keelelist käitumist võib tõlgendada T kontrollimehhanismina, mille abil ta saab aimu, kas vestluspartnerid on temast aru saanud (vt näiteks voorud 1-5).

T universaalne küsisõna on Öhö?, mis kombineeritult viibete ja/või žestidega võib toimida ükskõik millise eestikeelse küsisõna rollis. Vestlus algabki sellise küsimusega ja tähendab eesti keelde tõlgituna “Kus $S_{1}$ on?" või “Mida $S_{1}$ teeb?”. Õde hoiab vasakut kätt venna õlal, et viimane talle kindlasti vastaks. Füüsiline kontakt tagab suurema läheduse ja nii pole küsijat võimalik ignoreerida. ${ }^{9}$ Häälitsusele lisaks kasutab T eesti viipekeele viibet LAPS, s.t näitab käega madalale, maapinna lähedale, mis markeerib väikest kasvu inimest. Vend vastab, et $\mathrm{S}_{1}$ on kodus. Kuna see ei olnud soovitud vastus, pärib õde edasi, kasutades sama lihtsustatud küsimust (tähendusega silpi). Nüüd saab ta vastuseks, et $S_{1}$ mängib, kuid ka see pole loodetud vastus.

Ema, kes filmib, sekkub vestlusesse ja palub T-l uuesti näidata viibet LAPS. T kordabki viibet ja ka oma küsimust Öhö?, hoides samal ajal vasakut kätt venna õlal ja viibates parema käega kaugusesse. Niimoodi vaidleb ta vennale vastu väitega, et $\mathrm{S}_{1}$ on ju Pangodis. Samal ajal vaatab ta küsivalt vennale otsa, otsekui kontrollides, kas tema küsimusest saadi ikka aru (abiotsimine). Lausungitest 9 ja 10 ongi näha, et teised kaks vestluses osalejat proovivad teda üksteisele peale rääkides täpsustavate küsimustega aidata, millele T omakorda vastab jaatusüneemi kasutades.

9 Samuti on puudutus eraldi suhtlusmodaalsus, millega T loob oma suhtlusruumi. Sellele modaalsusele juhtisid 
Dialoogis ei tekiks tähendust ega seda poleks võimalik edasi arendada, kui vestluses osalejatel poleks ühiseid eelteadmisi. Samal teemal on varemgi räägitud ja seetõttu on vestlejatel lihtsam üksteist mõista.

Viibe, mis sel korral omab tähendust 'Pangodi', on eesti viipekeeles muidugi üldisem ja selle tähendused on 'seal' või 'kaugel'. T käeliigutused ei ole enamasti korrektsed viiped, ta on neid lihtsustanud ja endale mugavamalt sooritatavateks muutnud. Samuti kasutab tütarlaps žeste.

Analüüsitavas vestluses pakub psühholoogilist huvi lausung 22, kus T väidab, et talle meenub äkki, et temagi pidi Pangodisse külla minema. Selle mõtte väljendamine on väga keeruline intellektuaalne tegevus (meenutagem: tegemist on teatud kromosoomihäirega isikuga). Mõtte väljendamine on ilmekas, kaasatud on kogu keha, hääl ja näoilme. T koputab endale vastu rinda, see tähendab MINA, raputab siis kätt õhus - see märk näitab, et ta püüab midagi meelde tuletada, ja võtab lõpuks sõrmedega ninajuurest kinni. Kõneliselt venitab ta vokaali a, varieerides seda laias ulatuses ja ilmekalt. Tütarlapse ilme on samal ajal väga väljendusrikas, kortsus kulmuga murelik nägu, mis lööb särama, kui meenub see, mida meenutada taheti.

Tütarlaps saab ise kaasvestlejate jutust aru, mis teeb omakorda teistele temast arusaamise lihtsamaks. Samuti on T võimeline otsustama, kas tema jutt sai õigesti "tõlgitud". A. Kendonile (1986) tuginedes teame, et tähendused ei transformeeru žestideks ja kõneks ühel ja samal viisil. Žestid võidakse moodustada otse, iseseisvalt ja suulisest keelest ehk kõnest sõltumatult.

\section{Kokkuvõte}

Artiklis esitati multimodaalse suhtluse analüüs, milles näidati, kuidas suuline keel ehk kõnekeel üksi ei suuda kommunikatiivset tähendust esitada. Näidati tähenduse esilekerkimist osapoolte koostöö kaudu.$^{10}$ Suhtlusanalüüsi puhul arvestati eelnevaid traditsioone: vestlusanalüüsi metoodikat ja diskursusanalüüsi situatsioonikäsitlust. Multimodaalsete komponentide arvessevõtmisega kujuneb suhtlussituatsiooni parem mõistmine. Artikli materjalianalüüsis esitatud Patau sündroomiga tütarlapse suhtlusmustrid markeerivad selgelt videoainestiku eeliseid diktofonilindistuse ees. Videoainestik võimaldab jälgida suulise kõne ning käeliigutuste seost, mis diktofonilindistustes paratamatult varju jäävad või edastatakse ebatäielikul kujul, tuginedes uurija mälule ning üleskirjutustele. Tähtsuseta ei ole ka situatsiooni ning suhtluspartnerite detailse keelelise ja liigutusliku käitumise jälgimine nii sõnas, viipes kui pildis: mis toimub suhtluses? kuidas reageerivad suhtluse osapooled üksteise kaaspanustele? kes on aktiivsed ja passiivsed vestluspartnerid ja milline nende käitumine? millised on käeliigutuste ja sõnalise osa seosed või seoste puudumised jne? Situatsioon oli heaks näiteks koostegevusest, kus keel, kognitsioon ja tegevus on situatsiooni koostisosad. Selles situatsioonis osalejad püüavad oma erinevate modaalsustega hõlmata olulisi nähtusi ümbritsevast (nt objektile osutamine kauguses - Pangodi jms). Antud situatsioonianalüüsis oli tütarlaps võimeline edastama isegi minevikus toimunut ja tulevikus toimuma saavat. Kommunikatiivse situatsiooni dünaamiline toimimine ning selle analüüs annab rohkem võimalusi üksteisemõistmiseks igal suhtlustasandil.

10 Täname dr Paul Mcllvenny't Aalborgi Ülikoolist usu ülevalhoidmise eest diskursus- ja konversatsiooniuuringute teema tulevikku. 


\section{Transkriptsioonimärgid}

(.)

mikropaus (o,2 sekundit või lühem)

langev intonatsioon

? tõusev intonatsioon

[ pealerääkimise algus

] pealerääkimise lõpp

(( )) kommentaar

suurtähed (nt AHA) hääle kõvendamine

\section{Viidatud kirjandus}

Allik, Jüri; Tulving, Endel 2003. Ajas rändamine ja kronesteesia. - Akadeemia, 5 (170), 915-939.

Austin, John L. 1962. How to do Things with Words. Oxford: Clarendon Press.

Bavelas, Janet Beavin 1994. Gestures as part of speech: Methodological implications. A. Kendon (Ed.). Research on Language and Social Interaction. Special Issue on Gestures, 27 (3), 201-221. doi:10.1207/s15327973rlsi2703_3

Bavelas, Janet Beavin; Chovil, Nicole; Coates, Linda; Roe, Lori 1995. Gestures specialized for dialogue. - Personality and Social Psychology Bulletin, 21, 394-405. doi:10.1177/0146167295214010

Blumer, Herbert 1969. Symbolic Interactionism: Perspective and Method. Berkeley: University of California Press.

Calbris, Geneviève 1990. Semiotics of French Gesture. Bloomington: Indiana University Press.

Cassell, Justine; McNeill, David; McCullough, Karl-Erik 1999. Speech-gesture mismatches: Evidence for one underlying representation of linguistic and nonlinguistic information. - Pragmatics and Cognition, 7 (1), 1-33.

Cienki, Alan 1998. Metaphoric gestures and some of their relations to verbal metaphorical expressions. - J.-P. Koenig (Ed.). Discourse and Cognition: Bridging the Gap. Stanford, CA: Center for the Study of Language and Information, 189-204.

Clark, Herbert H. 1992. Arenas of Language Use. Chicago: University of Chicago Press.

Dijk, Teun A. van 1997. The study of discourse. Discourse as structure and process. - T. van Dijk (Ed.). Discourse Studies: A Multidisciplinary Introduction. Vol. 1. London: SAGE Publications, 1-34.

Duranti, Alessandro 1999. Linguistics Anthropology. Second edition. Cambridge Textbook in Linguistics. Cambridge: Cambridge University Press.

Fiske, John 1990. Introduction to Communication Studies. Second edition. London, New York: Routledge.

Goodwin, Charles 1981. Conversational Organization: Interaction between Speakers and Hearers. New York: Academic Press.

Goodwin, Charles 1986. Gestures as a resource for the organization of mutual orientation. Semiotica, 62 (1-2), 29-49.

Goodwin, Charles 2003. Pointing as situated practice. - Sotaro Kita (Ed.). Pointing: Where Language, Culture and Cognition Meet. Mahwah. NJ: Lawrence Erlbaum, 217-241.

Goodwin, Charles 2007. Environmentally coupled gestures. - Susan Duncan, Justine Cassell, Elena Levy (Eds.). Gesture and the Dynamic Dimensions of Language. Amsterdam/ Philadelphia: John Benjamins, 195-212.

Goodwin, Marjorie H.; Goodwin, Charles 1986. Gesture and coparticipation in the activity of searching for a word. - Semiotica, 62 (1-2), 51-72.

Gurevitš, Aron 1992. Keskaja inimese maailmapilt. Tallinn: Kunst.

Hakulinen, Auli 1986. Vestlus keelenähtusena. - Keel ja Kirjandus, 8, 449-458.

Hassinen, Sirje 2002. Simultaaninen kaksikielisyys: läheiset sukukielet viro ja suomi rinnakkain. Oulun yliopiston suomen ja saamen kielen ja logopedian laitos. 
Have, Paul ten 2004. Understanding Qualitative Research and Ethnomethodology. London, Thousand Oaks, New Delhi: Sage Publication.

Have, Paul ten 2006. Doing Conversation Analysis: A Practical Guide. 5th edition. London, Thousand Oaks, New Delhi: Sage Publication.

He, Agnes Weiyun 2003. Discourse analysis. - Mark Aronoff, Janie Rees-Miller (Eds.). The Handbook of Linguistics. London: Blackwell Publishers, 428-425.

Heath, Christian; Hindmarsh, Jon 2002. Analysing interaction: Video, ethnography and situated conduct. - T. May (Ed.). Qualitative Research in Action. London: Sage, 99-121.

Hennoste, Tiit 2003a. Keelekasutuse uurimine. - Emakeele Seltsi aastaraamat, 48 (2002), 217-262.

Hennoste, Tiit 2003b. Suulise eesti keele uurimine. - Keel ja Kirjandus, 7, 481-500.

Itkonen, Esa 2005. Analogy as Structure and Process: Approaches in Linguistics, Cognitive Psychology and Philosophy of Science. Human Cognitive Processing 14. Amsterdam/ Philadelphia: John Benjamins.

Jordan, Brigitte; Henderson, Austin 1995. Interaction analysis: Foundations and practice. - The Journal of the Learning Sciences, 4 (1), 39-103. doi:10.1207/s15327809jls0401_2

Kendon, Adam 1980. Gesticulation and speech: Two aspects of the process of utterance. Mary R. Key (Ed.). The Relationship of Verbal and Nonverbal Communication. The Hague: Mouton and Co., 207-227.

Kendon, Adam 1986. Current issues in the study of gesture. - Jan-Luc Nespoulous, Paul Perron, André Roch Lecours (Eds.). The Biological Foundations of Gestures. Hillsdale N.Y.: Lawrence Erlbaum Associates, 23-48.

Kendon, Adam 1995. Gestures as illocutionary and discourse structure markers in Southern Italian conversation. - Journal of Pragmatics, 23 (3), 247-279. doi:10.1016/o3782166(94)00037-F

Kendon, Adam 2001. Review article: Gesture as communication strategy. - Semiotica, 135 (1-4), 191-209. doi:10.1515/semi.2001.060

Kendon, Adam 2004. Gesture: Visible Action as Utterance. Cambridge: Cambridge University Press.

Kita, Sotaro 2000. How representational gestures help speaking. - David McNeill (Ed.). Language and Gesture. Language, Culture and Cognition 2. Cambridge: Cambridge University Press, $162-185$.

Koch, Walter A. 2001. Consciousness, communication, speech - a condensed view of the origins of language. http://www.trismegistos.com/IconicityInLanguage/Articles/ Koch/Koch.htm (12.12.2003).

Labov, William 1972. Sociolinguistic Patterns. Philadelphia: University of Pennsylvania Press.

Lehtonen, Heini 2004. Maahanmuuttajataustaisten helsinkiläisnuorten puheen variaatio ja monikielisyys. Pro gradu -tutkielma. Helsinki: Helsingin yliopiston suomen kielen laitos.

Levinson, Stephen C. 1983. Pragmatics. Cambridge: Cambridge University Press.

McNeill, David 1992. Hand and Mind: What Gestures Reveal About Thought. Chicago: University of Chicago Press.

McNeill, David 1999. One ontogenetic universal and several cross-linguistic differences in thinking for speaking. Based on a plenary lecture of the same title given at the 6th International Cognitive Linguistics Conference, Stockholm, Sweden, 13 July. Manuscript, 1-28.

Place, Ullin T. 1998. The role of the hand in the evolution of language. http://dbiref.kub. $\mathrm{nl}: 2080 / \sim$ place/utplace/HAND98.htm (20.06.2001).

Rees, Maria Agnes van 1992. The Use of Language in Conversation. Amsterdam: SICSAT International Society for the Study of Argumentation (ISSA). 
Rääbis, Andriela 200o. Telefonivestluste sissejuhatus. - Keel ja Kirjandus, 6, 409-424.

Rääbis, Andriela 2002. Ametlike telefonikõnede lõpetamine. - Emakeele Seltsi aastaraamat, 47 (2001), 107-125.

Sacks, Harvey; Schegloff, Emanuel; Jefferson, Gail 1974. A simplest systematics for the organization of turn taking for conversation. - Language, 50 (4), 696-735. doi:10.2307/412243

Schegloff, Emanuel A. 1984. On some gestures' relation to talk. - J. M. Atkinson, J. Heritage (Eds.). Structures of Social Action: Studies in Conversational Analysis. Cambridge: Cambridge University Press, 266-296.

Scollon, Ron; Scollon, Suzanne Wong 2001. Intercultural Communication: A Discourse Approach. 2nd ed. Cambridge, MA: Blackwell Publishers.

Sinha, Chris 2001. The epigenesis of symbolization. - C. Balkenius, J. Zlatev, H. Kozima, K. Dautenhahn, C. Breazeal (Eds.). Proceedings of the First International Workshop on Epigenetic Robotics. Lund: Lund University, 85.

Sinha, Chris 2005. Biology, culture and the emergence and elaboration of symbolization. Anjum P. Saleemi, Ocke-Schwen Bohn, Albert Gjedde (Eds.). In Search of a Language for the Mind-Brain: Can the Multiple Perspectives be Unified? Aarhus: Aarhus University Press, 311-335.

Streeck, Jürgen 1988. The significance of gesture: How it is established. - Papers in Pragmatics, 2 (1), 25-59.

Streeck, Jürgen; Knapp, Mark L. 1992. The interaction of visual and verbal features in human communication. - F. Poyatos (Ed.). Advances in Nonverbal Communication. Amsterdam/Philadelphia: John Benjamins, 3-24.

Tenjes, Silvi 2002. Kus keel ja käsi kokku saavad? - Renate Pajusalu, Ilona Tragel, Tiit Hennoste, Haldur Õim (toim.). Teoreetiline keeleteadus Eestis. Tartu Ülikooli üldkeeleteaduse õppetooli toimetised 4. Tartu: Tartu Ülikooli Kirjastus, 255-271.

Vuokila-Oikkonen, Päivi 2002. Akuutin psykiatrisen osastohoidon yhteistyöneuvottelun keskustelussa rakentuvat kertomukset. Oulun yliopiston hoitotieteen ja terveyshallinnon laitos.

Vuorinen, Pihla 2001. Oma pere ja tuttavate ringis tehtava uurimistöö valguse- ja varjupooled. - Tiiu Jaago (toim.). Pärimuslik ajalugu. Tartu: Eesti Kirjandusmuuseum, 235-244.

Wooffitt, Robin 2006. Conversation Analysis and Discourse Analysis. Second edition. London, etc.: SAGE Publications.

\section{Kaudviited}

Malinowski, Bronislaw 1978 [1935]. Coral Gardens and Their Magic: A Study of the Methods of Tilling the Soil and of Agricultural Rites in the Trobriand Islands. Vol. 2. New York: Dover Publications.

Mead, George Herbert 1934. Mind, Self, and Society: From the Standpoint of a Social Behaviorist. Chicago: University of Chicago Press.

Mead, George Herbert 1938. The Philosophy of the Act. Chicago: University of Chicago Press. 


\title{
THE DYNAMIC DIMENSION OF A COMIMUNICATIVE SITUATION
}

\author{
Silvi Tenjes, Ingrid Rummo, \\ Kristiina Praakli \\ University of Tartu
}

The current article presents an overview of a domain which has become essential as an intersection of social sciences and the humanities: research of human communication in a real situation, among this the describing of language usage in a multimodal way including all kinds of means that are available to the collocutors or used by them. Also, a survey of previous research upon the use of language (e.g. in sociolinguistics) is provided.

The communicative situation as a part of social activity includes, besides the spoken language of the communicators, also their bodily movements - glance, hand movement - and the situation as a whole. Currently research into language use serves as part of interdisciplinary investigations including conversation analysis, discourse analysis, research on multilingualism, anthropology, second language acquisition, micro sociology etc.

The researches carried out by sociologists are often called conversation analysis, while the investigations made mainly by linguists and sociolinguists are referred to as discourse analysis. These two fields of research differ from each other both in their objectives and methods, and this is a point discussed in the present article.

The main principles of studying speaking as a social activity are also viewed in the current article. The pioneers in the field as well as the founders of the method discussed and the guardians of its continuity are introduced.

The ability to communicate and physical experience have been important for a human being all through the existence of the thinking mankind. We discover the space surrounding us by means of various movements. Perception, memory and language are parts of human cognition. The way we see the world, our conception of it takes shape in a concrete social culture.

In communication it is possible to find three different types of information: info about cognition, motivation and the emotional condition of the speaker. The role of language is to play an active pragmatic part in the behaviour of a person.

In a communicative situation we are using different abilities of communication, among which the authors of the article mention analogy. The concept of icon is looked at more closely. Hand gestures are important factors in forwarding meanings and intentions; they are discussed in the part of the article where the creating of the meaning is in focus. The concept of multimodal communication is defined; the advantages of using video data in the process of gathering and analysing the material are presented. As an example the authors provide analysis of a communicative situation where one interlocutor is a 17-year-old girl with the mosaic variant of the Patau syndrome. While doing the conversational analysis the authors considered different traditions, combining, e.g., the method of conversational analysis with the treatment of situation typical of discourse analysis. The communication patterns 
of the girl with the Patau syndrome underline very clearly the advantage of video material over dictaphone recordings.

In their analysis the authors affirm that if one takes into consideration collaboration between the collocutors as well as the multimodal components, one will certainly get a better understanding of a communicative situation. The dynamic functioning of a communicative situation and our analysis of this process will give us more opportunities to understand each other on every level of communication.

Keywords: conversational analysis, discourse analysis, communication, nonverbal language, cognition, aphasias, Patau syndrome

Silvi Tenjes (Tartu Ülikool) on uurinud käeliigutusi, kõnekeelt ja kommunikatsiooni, metafoorsust, ruumisemantikat. Uurib suhtlust multimodaalses kommunikatsioonis ning sotsiaalses interaktsioonis. Huvitub tegevusrepresentatsiooni seosest tajuruumiga liigutuste sooritamiseks ning õppimiseks. silvi.tenjes@ut.ee

Ingrid Rummo (Tartu Ülikool) teaduslikud huvialad on arvutipõhine keeleõpe, eesti keele ortograafia küsimused, mitteverbaalne suhtlus, žesti- ja viipeuuringud, intellektipuue ja keel.

ingrid.rummo@ut.ee

Kristiina Praakli (Tartu Ülikool) teaduslike huvide hulka kuuluvad kontaktlingvistika, mitmekeelsuse (eriti koodivahetuse) ning suhtlusvõrgustike uuringud.

kristiina.praakli@ut.ee 